\title{
Uzavření škol: jiný příběh se stejným nadpisem? Zkušenosti ze tří zemí
}

\author{
Eva Minař́́ková \\ Masarykova univerzita, Pedagogická fakulta, Institut výzkumu školního vzdělávání
}

Koronavirus a následné uzavření škol nás všechny zastihly nepřipravené. Mě osobně zastihly nepřipravenou v kanadské provincii Saskatchewan. Bylo to období spojené s obavami, zrušenými plány na cestu do Evropy, ale i období fascinujícího porovnání toho, jak se moje dva světy vypořádaly s výzvou století (alespoň prozatím). A to se stalo inspirací pro tento text.

Jak se různé země vyrovnaly s přechodem na distanční vzdělávání? Co může být inspirací? Co naopak ne? V čem se přístupy liší a v čem se naopak podobají? Na to vše se pokusím odpovědět v následujících odstavcích na příkladu tř́ zemí, resp. provincií - Řecka, Španělska a Kanady (Saskatchewan). Uvedené se bude částečně vztahovat k situaci v ČR, její popis ale není předmětem textu, jelikož je čtenáři známá. Zdroje pro tento text tvoří výpovědi tří učitelů, kteří byli přímými účastníky uzavření škol (každý z jedné jmenované země), informace z médií a oficiálních webových stránek (vládních, školních) a přímé zkušenosti dvou rodičů. Je zřejmé, že výpověd' jednoho respondenta nemůže postihnout zkušenost celé země; jedná se spíše o ilustraci přístupu země, jak jej vnímá jeden konkrétní respondent z jedné konkrétní školy. Výběr respondentů byl dostupný; jedná se o kontakty, které měla autorka k dispozici. Respondentka z Řecka učí angličtinu na soukromé základní škole (první stupeň); není tř́ídní učitelkou. Kolegyně ze Španělska vyučuje na prvním stupni polostátní základní školy (concertada) a je třídní učitelkou v první tř́́dě. Učitel z provincie Saskatchewan pracuje na státní základní škole se žáky od první do deváté třídy a je zároveň třídním učitelem deváté třídy. Jeden z rodičů má dceru ve druhé třrídě základní školy v ČR; druhý rodič (já) měl v době uzavření škol syna ve druhé třídě francouzské imerzní školy v provincii Saskatchewan. Internetové zdroje byly vyhledávány k doplnění informací poskytnutých respondenty. Všichni respondenti písemně odpověděli na sadu otázek zaměřených na jejich profesní profil a organizační aspekt uzavření škol (komunikace, pokyny od vedení, náplň a zprostředkování učiva apod.). 
V následujícím textu se nejprve zaměříme na to, jak uzavření škol v jednotlivých zemích probíhalo, jaký prostor pro adaptaci měli učitelé, jak byl vybírán a zprostředkován obsah, jak bylo komunikováno se žáky i rodiči a jak probíhalo hodnocení.

\section{Uzavření škol}

Ve sledovaných zemích došlo k uzavření škol ve zhruba týdenním rozpětí. Řecko, podobně jako ČR, uzavření škol oznámilo v podvečer 10. března 2020 s platností od 11. března. Španělsko oficiálně uzavřelo školy od 13. března ${ }^{1}$, ale školy měly možnost toto rozhodnutí učinit i dříve. Toho využila i škola naší respondentky (12. března). V provincii Saskatchewan byla pandemie pod kontrolou déle (a dosud má celkem nízké počty nakažených). Provinční vláda oznámila uzavření škol v pondělí 16. 3. 2020 s platností od pátku 20. 3. $2020^{2}$, což byl plánovaný den volna v místních školách. Rodičům bylo doporučeno, aby - pokud mají tu možnost - neposílali děti do školy od následujícího dne. Rodiny tak měly možnost se připravit a najít alternativní způsoby péče o děti v průběhu dne.

V jednotlivých zemích se lišilo nejen datum, ale i způsob oznámení tohoto rozhodnutí. V Řecku, podle informací respondentky, tato informace zazněla z médií - tak se to dozvěděli rodiče, žáci i učitelé. Španělská respondentka měla možnost oznámit tuto zprávu žákům v průběhu posledního školního dne, jelikož její škola ukončila činnost o den dříve, než nařizovalo oficiální rozhodnutí. V kanadské provincii Saskatchewan vešlo rozhodnutí vlády ve známost $\mathrm{v}$ průběhu dne, učitelé tak měli možnost diskutovat nastalou situaci se žáky přímo. Rodičům byl odeslán oficiální dopis a automatická telefonní zpráva.

\section{Př́íprava na distanční vzdělávání}

Velké rozdíly panovaly $\mathrm{v}$ dění bezprostředně po oznámení uzavření škol. Řecká vláda vyhlásila, že tato situace bude trvat pouze dva týdny. Distanční vzdělávání proto nebylo předmětem diskusí, dokud se po 14 dnech neukázalo, že výjimečný stav bude trvat delší dobu. Teprve poté ministerstvo školství

1 https://www.catalannews.com/society-science/item/closure-of-schools-and-universitiescomes-into-force-with-1-8m-students-affected

2 https://globalnews.ca/news/6683648/schools-saskatchewan-closing-covid-19coronavirus/ 
začalo vydávat pokyny $\mathrm{k}$ implementaci náhradní formy vzdělávání. Jelikož ale respondentka působí na soukromé škole, začala s kolegy s distančním vzděláváním okamžitě, tudíž bez času na přípravu. Podobná situace jako na této škole byla i na pracovišti španělské respondentky. Př́iprava na přechod na distanční vzdělávání začala druhý den po uzavření školy. Naprosto odlišná situace byla v kanadské provincii Saskatchewan. Rodiče měli možnost posílat děti do školy několik dní po oficiálním oznámení o uzavření škol; první týden po uzavření si pak školy a školní divize ${ }^{3}$ vzaly na ustavení rozhodujících orgánů a formování předběžných plánů. Druhý týden následovala pauza, ve které ustavené orgány plánovaly další postup a učitelé a žáci se dle oficiálních informací měli soustředit na adaptaci na novou situaci a vlastní duševní zdraví. Ve třetím týdnu se učitelé spojili se jednotlivými rodinami, aby se seznámili s jejich situací (emoční, zdravotní, technologickou) a domluvili se na preferovaném způsobu kontaktu. $V$ mém konkrétním případě paní učitelka kontaktovala rodinu pomocí Google dotazníku, ve kterém zjištovala možnosti připojení na internet, tisku a obecně komunikace se školou. Čtvrtý týden následovaly jarní (velikonoční) prázdniny. Dle výpovědi respondenta i vlastní zkušenosti skutečné distanční vzdělávání organizované školou začalo až 20. dubna. Do té doby měli rodiče $\mathrm{k}$ dispozici generické online materiály na stránkách škol a školních divizí, ale jejich využívání záleželo na jejich rozhodnutí.

Důležité je podotknout, jakou podporu dostávali učitelé z „vyšších míst“. Všichni se vyjádřili ohledně dobré komunikace na úrovni školy. V kanadském prostředí byl nicméně zřejmý mezistupeň organizace a podpory (mezi provincií a školou), který respondentky z Řecka a Španělska neuváděly - školní divize. Ty si vzaly čas na organizaci. Učitelé byli aktivně informováni o vývoji situace jak ze strany školy, tak i ze strany samotné divize. Co nejdř́ve po uzavření škol bylo učitelům sděleno, kdo a jak bude o postupu divize rozhodovat, od koho a jak mohou učitelé očekávat informace, pokyny a podporu a jaký je předběžný časový harmonogram zavádění distančního vzdělávání. $\mathrm{Z}$ odpovědi respondenta vyplývalo, že tento postup poskytl oporu a jistotu v nejisté době. Tento pocit v odpovědích ostatních respondentek chyběl.

3 Školní divize (school divisions) jsou v provincii Saskatchewan organizační jednotky, které sdružují školy na základě místní příslušnosti a typu školy (veřejné školy, římskokatolické školy). Největší školní divize (Saskatoon Public Schools) zahrnuje 49 základních škol (věk 4 až 14 let), 10 středních škol (14 až 18 let) a tři afilované školy (https://en.wikipedia.org/ wiki/List_of_school_divisions_in_Saskatchewan). 
Téma podpory bylo pro kanadského respondenta významné. Zmiňoval například přítomnost speciální IT podpory na každé škole a pravidelné nabídky profesního vzdělávání.

\section{Obsah vzdělávání}

Velkou otázkou nastalé situace byl obsah nové formy vzdělávání. V Řecku byl původní pokyn nezahrnovat nové obsahy a soustředit se pouze na opakování. Tento přístup se ale v průběhu času ukázal jako neudržitelný a byl pozměněn. $V$ provincii Saskatchewan (minimálně ve školní divizi respondenta) byl obsah ponechán na učitelích. Bylo na jejich zvážení, jaký obsah jim zbývá do konce roku probrat a co z něj považují za stěžejní. Španělská respondentka se ve svých materiálech soustředila na opakování a nové učivo představovala pouze skrze zábavné aktivity a hry tak, aby ti, kteří distančně pracovat nemohou, nezameškali. $Z$ její odpovědi ale nebylo zřejmé, zda se jednalo o pokyn shora či o důsledek toho, že se jednalo o první ročník.

Co se týče vytížení žáků, pro žáky na prvním stupni učitelka ze Španělská plánovala cca tři hodiny práce denně, které zahrnovaly čas na čtení, přestávky, hry a tvořivé aktivity. Učitelé $v$ divizi kanadského respondenta měli za úkol připravit práci v rozsahu dvou až tří hodin týdně za každý předmět. Studenti ale neměli být penalizováni, pokud práci nedodají. Z osobní zkušenosti: obsah práce pro žáka druhé tř́ídy sestával z jednoho úkolu psaní (zpravidla jedna až dvě věty), čtení jedné krátké knihy, dvou až tří úkolů z matematiky (zpravidla prostřednictvím aplikace Mathletics) a jednoho videa z náboženství (jednalo se o katolickou školu).

\section{Zprostř̌edkování obsahu}

Co se týče zprostředkování obsahu a komunikace, volba byla ponechána na školách a na učitelích. Španělská a řecká respondentka zmiňují vlastní školní platformu, doplněnou o telefonní kontakt s nedostupnými rodiči (Španělsko), videohovory (Španělsko), některé Google nástroje (obě země) a další online zdroje (obě země). Dle vyjádření kanadského respondenta, ačkoliv byla učitelům ponechána možnost volby, většina jeho kolegů zvolila Google Classroom a Google Meet. Respondentka z Řecka nezmiňuje synchronní výuku/komunikaci. Španělská respondentka organizovala pravidelné týdenní hovory s třídou rozdělenou do skupin po pěti až šesti žácích. V provincii Saskatchewan 
učitelé synchronní výuku zařazovali dle uvážení. Většina nabádala rodiče a žáky, aby je kontaktovali i individuálně prostřednictvím Google Meet.

$\mathrm{V}$ případě, že žáci neměli přístup $\mathrm{k}$ technologiím potřebným pro distanční vzdělávání, jim španělská vláda poskytla notebooky. V Kanadě byly notebooky poskytovány školou, stejně jako hotspot pro žáky bez přístupu k internetu. V Řecku byla tato opatření slíbena, ale do doby sběru dat neprovedena.

\section{Hodnocení}

Ve všech zemích učitelé poskytovali žákům online zpětnou vazbu k odevzdané práci prostřednictvím zvolených platforem (zpravidla formou komentářů) a v průběhu videohovorů. Oficiální hodnocení neprobíhalo. Zhodnocení práce se mohlo promítnout do závěrečného hodnocení jako „Zaokrouhlení“ známky ve Španělsku a jen v př́ípadě zlepšení stupně v Kanadě.

\section{Zpětná vazba od rodin}

Zajímavé jsou rozdíly v tom, jak bylo pracováno se zpětnou vazbou od rodin/rodičů. Řecká ani španělská učitelka oficiální zpětnou vazbu nezmiňují, jen monitorování žáků prostřednictvím odevzdaných pracovních listů, úkolů a skrze videohovory. V provincii Saskatchewan ale se zpětnou vazbou od rodin bylo pracováno průběžně. Jak bylo zmíněno výše, před začátkem distančního vzdělávání měli učitelé za úkol spojit se s rodinami ( $\mathrm{v}$ našem př́́padě skrze online dotazník) a zjistit jejich zázemí a možnosti. V průběhu jara si pak školní divize vyžádala zpětnou vazbu od učitelů ohledně účasti žáků, obav rodičů apod. Učitelé tuto zpětnou vazbu získávali různě, zpravidla však skrze online dotazník.

\section{Jarní prognóza}

V tomto bodě byly také rozdíly. Ve provincii Saskatchewan bylo od začátku uzavření škol počítáno s tím, že žáci do škol nastoupí nejdříve v září. Řecko a Španělsko takto jasné stanovisko neměly a prognóza se v průběhu jara vyvíjela (podobně jako v ČR). V divizi kanadského respondenta distanční vyučování skončilo již 15. června (oproti tradičnímu konci června), aby učitelé mohli využít ušetřené dva týdny na plánování podzimní výuky. Každý učitel musel mít plán jak na prezenční, tak na distanční výuku (podle hesla doufejte v nejlepší, připravte se na nejhorší). Ustanoveny byly také skupiny učitelů 
stejných předmětů napříč školami. Zde mohou učitelé sdílet nápady, jak organizovat výuku i za nových protiepidemických opatření.

\section{Závěrem}

Tento text měl za cíl poskytnout výběrový pohled do procesu uzavření škol ve třech zemích - Kanadě (provincie Saskatchewan), Španělsku a Řecku. Shrnuli jsme rozdíly a podobnosti v postupu uzavření škol a distančním vzdělávání jako takovém. Připomínáme, že některé údaje jsou reprezentativní za celou diskutovanou zemi (např. data uzavření škol), zatímco na jiné je potřeba nahlížet jako na specifické, ovlivněné vnímáním a prožíváním konkrétních respondentů v kontextu jejich škol. I přesto mohou být zmiňované postupy inspirací či nabídnout zrcadlo a možnost zamyslet se nad vlastním přístupem.

Ačkoliv se jednotlivě země a školy lišily v organizaci, informovanosti a podpoře učitelů, ze všech odpovědí vyplývalo jediné - hluboký zájem respondentů o své žáky, jejich učení a duševní pohodu.

\subsection{Postskriptum ze zář́}

V naší školní divizi nebylo přes léto dlouho jasné, jak se bude v září pokračovat. $V$ průběhu srpna došlo $\mathrm{k}$ odložení začátku školy o týden. Rodinám byly nabídnuty tři varianty - domácí vzdělávání (klasická forma bez větší účasti školy), prezenční vzdělávání (klasická podoba se zohledněním aktuálních protiepidemických opatření) a distanční vzdělávání (ve stabilních online skupinách; s podílem synchronní a asynchronní výuky). Poslední zmíněné bylo nejdříve nabízeno jen pro anglickou větev, po velkém zájmu i pro francouzskou imerzní větev. Bylo také přislíbeno, že bude umožněn přechod mezi distančním a prezenčním vzděláváním oběma směry, a to pravděpodobně v předem určených termínech. Co se týče prezenční výuky, v polovině srpna byl všem rodičům zaslán přehled opatření, která budou ve škole platit (např. nestřídání učeben, značení na chodbách, pravidla nošení roušek), a souhrn toho, jak se bude postupovat v případě potvrzené nákazy ve škole.

\section{Autor}

Mgr. Eva Minaříková, Ph.D., Masarykova univerzita, Pedagogická fakulta, Institut výzkumu školního vzdělávání, Poříčí 31, 60300 Brno, e-mail: minarikova@ped.muni.cz 